Check for updates

Cite this: RSC Adv., 2017, 7, 47279

Received 1st August 2017

Accepted 22nd September 2017

DOI: $10.1039 / \mathrm{c} 7 \mathrm{ra0} 8507 a$

rsc.li/rsc-advances

\section{Fatty acid decarboxylation reaction kinetics and pathway of co-conversion with amino acid on supported iron oxide catalysts}

\begin{abstract}
Junjie Bian, (D) * Yue Wang, Qi Zhang, Xudong Fang, Lijuan Feng and Chunhu Li
$\mathrm{Fe}_{2} \mathrm{O}_{3} / \mathrm{Al}-\mathrm{MCM}-41$ nanocomposite catalysts were designed and fabricated to upgrade microalgae hydrothermal liquefaction (HTL)-derived biocrude and its model compounds (palmitic acid and glutamic acid) in the absence of hydrogen. The $\mathrm{Fe}_{2} \mathrm{O}_{3} / \mathrm{Al}-\mathrm{MCM}-41$ catalysts were prepared by encapsulating $\mathrm{Fe}_{2} \mathrm{O}_{3}$ particles on highly stable pure silica MCM-41 and Al-MCM-41. XRD, TEM, $\mathrm{N}_{2}$ adsorption isotherms, XPS, and UV-Vis characterizations of the catalysts revealed that $10-30 \mathrm{~nm} \gamma-\mathrm{Fe}_{2} \mathrm{O}_{3}$ particles were well dispersed on the mesoporous support. In the range of $320-350{ }^{\circ} \mathrm{C}$ and under subcritical water, palmitic acid conversion was improved by $43-54 \%$ by the $\mathrm{Fe}_{2} \mathrm{O}_{3} / \mathrm{Al}-\mathrm{MCM}-41$ catalyst. The overall reaction rate was first order to palmitic acid for non-catalytic and catalytic conversions, and the activation energy was $336.76 \mathrm{~kJ} \mathrm{~mol}^{-1}$ for $\mathrm{Fe}_{2} \mathrm{O}_{3} / \mathrm{Al}-\mathrm{MCM}$-41. In situ DRIFTS reaction test demonstrated that the initiation temperature for the catalytic decarboxylation of palmitic acid was decreased to $195{ }^{\circ} \mathrm{C}$, and desorption of the produced $\mathrm{CO}_{2}$ occurred at $255^{\circ} \mathrm{C}$. Based on the GC-MS results of the $\mathrm{HTL}$ products, the reaction pathway of the binary mixture of palmitic acid and glutamic acid was elucidated, and the chemical origins of amide, pyrrolidinone, hydroxy-butanoic acid, and pentadecane were proposed.
\end{abstract}

\section{Introduction}

Biomass conversion to biofuel or valuable chemicals offers an approach to sustainable, renewable energy. ${ }^{1-3}$ Microalgae is unique because of its relatively high photosynthetic efficiency, faster growth rate, and area-specific yield when compared with terrestrial plants. ${ }^{\mathbf{4} 5}$ Thermochemical procedures are feasible for both dry (pyrolysis) and wet biomass conversion (hydrothermal liquefaction, HTL), and the latter can be carried out under mild conditions because there is no lignocellulose in the microalgae cell. ${ }^{6}$

Microalgae HTL is considered an energy-efficient, environmentally friendly process, especially when (sub-) critical water is employed as a solvent and a reactant. ${ }^{-9}$ However, the derived biocrude consists of a wide variety of compounds introduced from the decomposition of proteins, lipids, and carbohydrates or from binary mixtures of amino acids and fatty acids, amino acids and carbohydrates, or fatty acids and carbohydrates. ${ }^{10}$ Because the levels of oxygen and nitrogen contaminants are several times higher in biocrude than in traditional fossil fuels, further upgrading (deoxygenation and denitrification) the HTLderived oil while simultaneously decreasing its acidity and increasing its stability is crucial. ${ }^{11}$

Key Laboratory of Marine Chemistry Theory and Technology of Ministry of Education, Ocean University of China, Qingdao 266100, Shandong, China. E-mail: junjiebian@ ouc.edu.cn
Previous researchers have exploited the ability of algae or its hydrolysis products to undergo the HTL process to obtain biocrude with lower oxygen content and higher heat value compared to the feed. Zeolites and mesoporous catalysts have been employed for algae HTL and showed good performance under relatively mild reaction conditions. Various zeolite supported non-sulfide catalysts such as noble metal(s) supported on non-sulfide zeolite catalysts such as noble metal supported on ZSM-5, HZSM-5, SAPO-11, beta-, Y-zeolite, SBA-15 and MCM41 mesoporous materials showed considerable activity for biofuel conversion. ${ }^{12,13} \mathrm{MgO} / \mathrm{MCM}-41$ was used in the catalytic HTL of Dunaliella tertiolecta for the production of bio-oil, and the catalyst was conducive to the improvement of conversion and bio-oil yield. ${ }^{\mathbf{1 4}}$ The catalytic HTL of Dunaliella tertiolecta was performed on multifunctional SBA-15-based catalysts; high contents of furfural and its derivatives along with low contents of acids, N-containing compounds, and esters were obtained when $\mathrm{NH}_{2}-\mathrm{SO}_{3} \mathrm{H}-\mathrm{Co}-\mathrm{SBA}-15$ and $\mathrm{SO}_{3} \mathrm{H}-\mathrm{Co}-\mathrm{SBA}-15$ were used as catalysts. ${ }^{15}$

Upgrading studies have been employed to improve the quality of algae-derived oil and to eliminate oxygen and/or nitrogen containing compounds. In addition to hydrogenation and hydrotreating, the deoxygenation of oxygenated model compounds (i.e., fatty acids and esters) in the absence of hydrogen provides another efficient approach for upgrading bio-oil. The cost-intensive noble metal (Pt and Pd)-based catalysts showed remarkable performance for decarboxylation and decarbonylation. Savage et al. ${ }^{16}$ Fu et al. ${ }^{17}$ Strathmann et al. ${ }^{18}$ 
and Kudo et al. ${ }^{19}$ recently reported the deoxygenation of bio-oil via deCO$_{x}$ and cracking over precious metal-based catalysts. It is necessary to develop alternative catalysts such as less expensive catalysts that have high deoxygenation ability for selective $\mathrm{deCO}_{x}$ reaction. Ni nanoparticle catalysts have been investigated for the deoxygenation of fatty acids, ${ }^{\mathbf{2 0 - 2 2}}$ and controlling the sizes, shapes, compositions and surface properties of these catalysts resulted in good performance for lipid conversion. Bian's group employed the optimized $\mathrm{Fe}_{2} \mathrm{O}_{3} / \mathrm{MCM}-41$ catalyst for chlorella HTL and for the derived bio-oil in situ upgrading. At $342{ }^{\circ} \mathrm{C}$, methyl palmitate conversion was $56 \%$, and the decarboxylation selectivity for pentadecane was improved to $62 \%$ on the catalyst in sub-critical water. ${ }^{23}$ Karnjanakom et al. developed Mg-doped Al-MCM-41 for the in situ catalytic upgrading of bio-oils. Mg/Al-MCM-41 exhibited the highly selective conversion of bio-oils derived from cellulose, lignin, or sunflower stalk to high-value-added aromatic hydrocarbons via catalytic cracking, deoxygenation and aromatization. ${ }^{24}$ Crocker et al. employed a Ni-Al layered double hydroxide catalyst for the deoxygenation of purified algae oil at $300{ }^{\circ} \mathrm{C}$ and obtained diesel-like $\left(\mathrm{C}_{10}-\mathrm{C}_{20}\right)$ hydrocarbons constituting $76 \mathrm{wt} \%$ of the liquid after $4 \mathrm{~h}$ on stream. ${ }^{25}$ Lee et al. demonstrated the deoxygenation of triolein towards paraffin catalyzed by $\mathrm{NiO}-\mathrm{CaO} /$ $\mathrm{SiO}_{2}-\mathrm{Al}_{2} \mathrm{O}_{3}$, and the maximum yield of straight-chain hydrocarbons $(73.3 \%)$ was achieved under the following deoxygenation condition: $7 \mathrm{wt} \%$ of catalyst, $340{ }^{\circ} \mathrm{C}$, within $60 \mathrm{~min} .{ }^{26}$

This study aims to design and fabricate supported iron oxide catalysts for in situ upgrading of model compounds those are abundant in the chlorella HTL derived oil. In this paper, the effects of the prepared $\mathrm{Fe}_{2} \mathrm{O}_{3} / \mathrm{MCM}-41$ catalysts on the deoxygenation of a lipid compound (palmitic acid) are explored, and kinetic analysis is carried out. The binary interactions of fatty acids and amino acids on the iron oxide catalysts are exploited to identify the possible reaction mechanism.

\section{Experiments}

\subsection{Catalyst preparation}

A typical preparation procedure of $\mathrm{Fe}_{2} \mathrm{O}_{3} /(\mathrm{Al}-) \mathrm{MCM}-41$ catalysts is described in Fig. 1. A certain amount of $\mathrm{FeCl}_{3} \cdot 6 \mathrm{H}_{2} \mathrm{O}$ (AR, Tianjin Basf Chemical Co., Ltd.) was dissolved in deionized water to obtain a $0.3 \mathrm{~mol} \mathrm{~L}{ }^{-1}$ solution. Ammonia water was quickly added to adjust the $\mathrm{pH}$ to 11 . Then, $10 \mathrm{~mL}$ of sodium citrate (AR, Tianjin Basf Chemical Co., Ltd.) solution was added. The obtained suspension was mixed with hexadecyltrimethyl ammonium bromide (CTAB, AR, Sinopharm Chemical Reagent Co. Ltd) solution. Then, $2 \mathrm{~g} \mathrm{Na} \mathrm{SiO}_{3} \cdot 9 \mathrm{H}_{2} \mathrm{O}$ (AR, Tianjin Basf Chemical Co. Ltd) was added slowly with stirring. The $\mathrm{pH}$ was adjusted to 10 to obtain mother liquid I, which was hydrothermally crystalized to obtain $\mathrm{Fe}_{2} \mathrm{O}_{3} / \mathrm{MCM}-41$. Otherwise, after $4 \mathrm{~h}$ of aging, $2 \mathrm{~g}$ CTAB was added to liquid I; subsequently, $1.0 \mathrm{~g}$ natural clinoptilolite (Shandong Jinshan Chemical Co. Ltd) was treated with $4 \mathrm{~mol} \mathrm{~L}^{-1} \mathrm{NaOH}$ (AR, Tianjin Basf Chemical Co., Ltd.) solution at $40{ }^{\circ} \mathrm{C}$ for $4 \mathrm{~h}$ to obtain colloid I, which was injected into liquid I. Concentrated sulfuric acid solution was added dropwise to adjust the $\mathrm{pH}$ of the mixture to 10.0 , and $40 \mathrm{~g}$ $\mathrm{Na}_{2} \mathrm{SiO}_{3} \cdot 9 \mathrm{H}_{2} \mathrm{O}$ was added. After aging for $4 \mathrm{~h}$, the colloidal

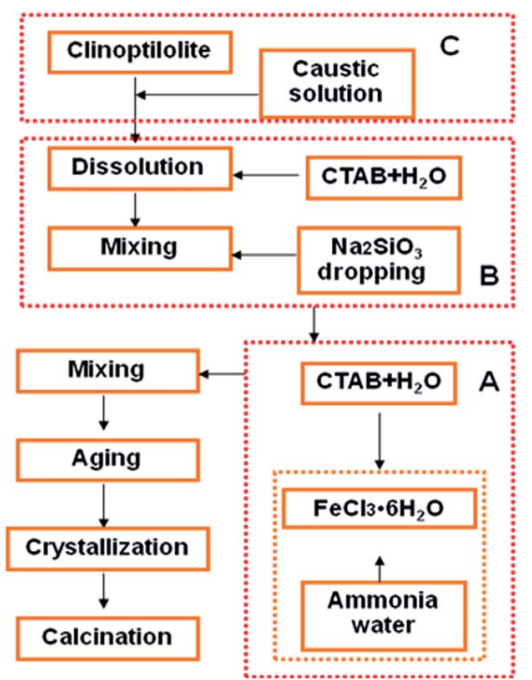

Fig. 1 Preparation route for $\mathrm{Fe}_{2} \mathrm{O}_{3} / \mathrm{MCM}-41(\mathrm{~A}+\mathrm{B})$ and $\mathrm{Fe}_{2} \mathrm{O}_{3} / \mathrm{Al}-$ MCM-41 catalysts $(A+(C+B))$.

solution was available. The mixture was then transferred into a Teflon-lined steel autoclave and statically heated at $120{ }^{\circ} \mathrm{C}$ for $48 \mathrm{~h}$. The product was dried, washed, filtered and calcined at $550{ }^{\circ} \mathrm{C}$ for $5 \mathrm{~h}$ with a heating rate of $10{ }^{\circ} \mathrm{C} \mathrm{min}{ }^{-1}$. Finally, the sample was designated as $\mathrm{Fe}_{2} \mathrm{O}_{3} / \mathrm{Al}-\mathrm{MCM}-41$.

\subsection{Catalyst characterization}

Powder X-ray diffraction (XRD) analysis was carried out using a Bruker D8 ADVANCE diffractometer (wavelength $=0.154 \mathrm{~nm}$, $\mathrm{CuK} \alpha$ ) for phase identification. Before measurements, the samples were degassed in a vacuum at $160{ }^{\circ} \mathrm{C}$ for $10 \mathrm{~h}$.

Transmission electron microscopy (TEM) was carried out with a JEM 2100 microscope (Japan) operated at $200 \mathrm{kV}$. The samples were ultrasonically dispersed in ethanol and laid on a Formvar-coated 200-mesh $\mathrm{Cu}$ grid.

UV-Vis diffuse reflectance (DR) spectra of the catalysts were collected on a Hitachi U-4100 spectrometer equipped with a diffuse reflectance attachment. An integrating sphere was coated with $\mathrm{BaSO}_{4}$ and used as a reference. The absorption intensity was expressed using the Kubelka-Munk function. The powder sample was loaded into a quartz cell, and the spectra were collected at $200-2500 \mathrm{~nm}$.

X-ray photoelectron spectroscopy (XPS) measurements of the chars were carried out using a Thermo VG-Scientific, Sigma Probe spectrometer (ESCALAB250, USA) with monochromatized $\mathrm{Al} \mathrm{K} \alpha$ radiation $(1486.92 \mathrm{eV}$ ) in constant analyzer energy mode. The pass energy was $70 \mathrm{eV}$ for survey spectra and $20 \mathrm{eV}$ for highresolution spectra.

An in situ DRIFTS reaction study of palmitic acid HTL decarboxylation was conducted using a Nicolet 6700 instrument. A high-pressure, high-temperature chamber fitted with $\mathrm{ZnSe}$ windows was utilized. Scans were taken at a resolution of $4 \AA$, and 128 scans were taken to improve the signal-to-noise ratio. Palmitic acid and glutamic acid (with $1: 1$ weight ratio) were pre-adsorbed on the catalyst powder, and about $30 \mathrm{mg}$ 
powder was loaded into the chamber. A steam generator consisted of a down flow tube and was equipped with an internal thermocouple.

\subsection{Catalytic activity evaluation}

The HTL of chlorella and model compounds was carried out in a custom stainless-steel autoclave micro-reactor (10 mL volume) equipped with a sand-bath electric furnace and a thermocouple. In a typical test, $150 \mathrm{mg}$ of reactant(s), such as palmitic acid or a mixture of palmitic acid (75 mg) and glutamic acid (75 mg), was injected into the reactor containing $10 \mathrm{mg}$ catalyst and $2 \mathrm{~mL}$ distilled water. Liquefaction experiments performed at $320{ }^{\circ} \mathrm{C}$, $327{ }^{\circ} \mathrm{C}, 335{ }^{\circ} \mathrm{C}, 342{ }^{\circ} \mathrm{C}$, and $350{ }^{\circ} \mathrm{C}$. After maintaining the temperature for $2.0 \mathrm{~h}$, the autoclave was quenched rapidly to room temperature, and liquid products were collected in a comparison tube for further characterization.

\subsection{Product analysis}

Liquid samples were dissolved in $2 \mathrm{~mL} n$-heptane, and $200 \mathrm{mg}$ methanol containing drops of concentrated sulfuric acid was added followed by esterification for gas chromatography (GC) analysis. Component identification was carried out on an Agilent Technologies 6890N GC equipped with a thermal conductivity detector (FID). The capillary column for GC and FID was a DB-WAX column $(30 \mathrm{~m} \times 0.25 \mathrm{~mm} \times 0.25 \mu \mathrm{m})$. The carrier gas was nitrogen at a flow rate of $40 \mathrm{~mL} \mathrm{~min}^{-1}$. A volume of $1 \mu \mathrm{L}$ was injected for each sample with a split ratio of $1 / 50$. The injector and detector temperatures were $250^{\circ}$ and $280{ }^{\circ} \mathrm{C}$, respectively. GC followed the following temperature program: hold at $50{ }^{\circ} \mathrm{C}$ for $1 \mathrm{~min}$ and increase to $200{ }^{\circ} \mathrm{C}$ at a heating rate of $25{ }^{\circ} \mathrm{C} \min ^{-1}$. Further identification of liquid products was done on an Agilent GC-MS (7890A-5975C).

Elemental analysis was carried out using a Vario EL III analyzer (CHN model), and the higher heat value was calculated from the Dulong equation.

\section{Results and discussion}

\subsection{Physicochemical properties of the catalysts}

Fig. 2 shows the XRD patterns of the prepared $\mathrm{Fe}_{2} \mathrm{O}_{3} / \mathrm{MCM}-41$ and $\mathrm{Fe}_{2} \mathrm{O}_{3} / \mathrm{Al}-\mathrm{MCM}-41$ catalysts. In the large-angle range, the diffraction peaks at $31.66^{\circ}, 35.56^{\circ}, 43.28^{\circ}$, and $57.36^{\circ}$ are attributed to the (220), (311), (400), and (511) reflections of maghemite $\left(\gamma-\mathrm{Fe}_{2} \mathrm{O}_{3}\right.$; referenced to JCPDS 25-1402).$^{27,28}$ Mineral clinoptilolite was employed as an aluminum source. This caused the prepared $\mathrm{Fe}_{2} \mathrm{O}_{3} / \mathrm{Al}-\mathrm{MCM}-41$ [Fig. 2(b)] to possess secondary units of natural zeolite, which was extraordinarily stable under hydrothermal and acidic conditions. $\mathrm{Fe}_{2} \mathrm{O}_{3} / \mathrm{Al}-$ MCM-41 retained the typical diffraction peaks of the monoclinic crystal system, with the strongest peaks appearing at $2 \theta$ values of $22.49^{\circ}, 26.05^{\circ}, 30.16^{\circ}$, and $32.02^{\circ}$; these peaks are coincident with the standard clinoptilolite PDF card JCPDS 330664 and JCPDS 39-1346. ${ }^{29}$ The good hydrothermal stability of the catalyst was attributed to the existence of clinoptilolite crystalline phase.

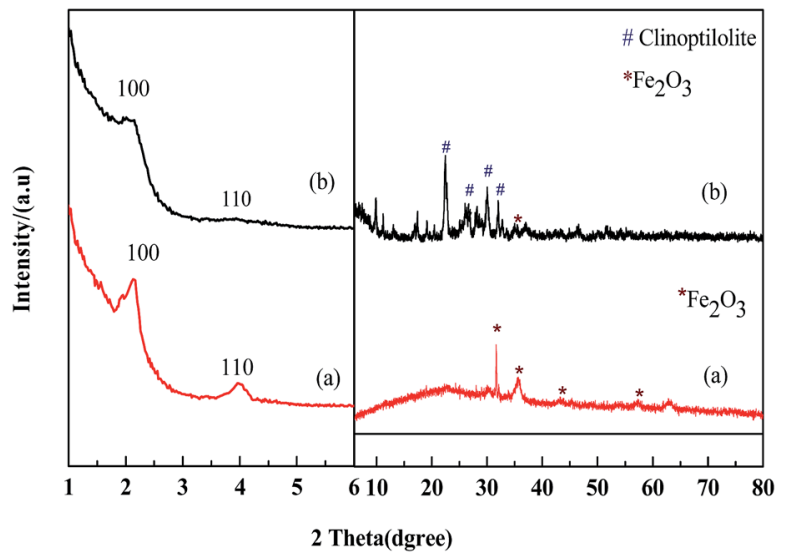

Fig. 2 Small-angle and large-angle XRD patterns of catalysts. (a) $\mathrm{Fe}_{2} \mathrm{O}_{3} / \mathrm{MCM}-41$ and (b) $\mathrm{Fe}_{2} \mathrm{O}_{3} / \mathrm{Al}-\mathrm{MCM}-41$.

In the small-angle regime, the lab-synthesized pure silicon MCM-41 showed three diffraction peaks corresponding to $d$ spacings of $3.84,2.26$ and $1.90 \mathrm{~nm}$, which can be indexed to the (100), (110) and (200) reflections of the hexagonal $(p 6 m)$ lattice of MCM-41. ${ }^{23}$ The $\mathrm{Fe}_{2} \mathrm{O}_{3} / \mathrm{MCM}-41$ catalyst showed an obvious (100) peak, and this peak indicates structural regularity. The supported catalysts kept mesoporous structure of MCM-41 type silica. $\mathrm{Fe}_{2} \mathrm{O}_{3} / \mathrm{MCM}-41$ exhibited broad diffraction peaks at $2 \theta$ values of $2.4^{\circ}$ and $4.3^{\circ}$ attributable to the (110) and (110) reflections, respectively. With the addition of aluminum, $\mathrm{Fe}_{2} \mathrm{O}_{3}$ / Al-MCM-41 exhibited two weaker peaks of the hexagonal structure at $2.4^{\circ}$ and $4.3^{\circ}$. The mesoporous structure was slightly affected by iron oxide incorporation, and it indicated that the $\mathrm{Fe}_{2} \mathrm{O}_{3} /(\mathrm{Al}-) \mathrm{MCM}-41$ catalysts could be well fabricated by assembling method. The prepared magnetic catalysts were chosen as HTL and decarboxylation catalysts for their reasonable distribution of active sites and good structural stability.

The main structural and textural characteristics of the prepared catalysts were determined from nitrogen adsorptiondesorption isotherms. Both isotherms are type IV with hysteresis loop 25, which is characteristic of mesoporous materials. In Fig. 3(a), $\mathrm{Fe}_{2} \mathrm{O}_{3} / \mathrm{MCM}-41$ shows a $\mathrm{H} 2$-type loop with the pore size distribution centered at 2.5 and $7.4 \mathrm{~nm}$. In Fig. 3(b). $\mathrm{Fe}_{2} \mathrm{O}_{3} / \mathrm{Al}-$ MCM-41 shows an H1 loop and a sharp inflection in the relative pressure $\left(p / p_{0}\right)$ between 0.2 and 0.3 , which corresponds to capillary condensation inside uniform mesopores. The sharpness of this step demonstrates the narrow pore size distribution centered at $2.6 \mathrm{~nm}$. This indicates that $\mathrm{Fe}_{2} \mathrm{O}_{3} / \mathrm{Al}-\mathrm{MCM}-41$ maintained the mesoporous structure of $\mathrm{Fe}_{2} \mathrm{O}_{3} / \mathrm{MCM}-41$ and enhanced the uniform hexagonal characteristics of MCM-41. $\mathrm{Fe}_{2} \mathrm{O}_{3} / \mathrm{Al}-\mathrm{MCM}-41$ provided active sites both for algae decomposition during HTL and fatty acid deoxygenation. ${ }^{23}$

In Fig. 4, the TEM micrographs of the prepared catalysts show an ordered hexagonal pore structure with embedded $\mathrm{Fe}_{2} \mathrm{O}_{3}$ nanoparticles. The TEM images of magnetic $\mathrm{Fe}_{2} \mathrm{O}_{3} /(\mathrm{Al}-)$ MCM-41 revealed that $10-30 \mathrm{~nm} \mathrm{Fe}_{2} \mathrm{O}_{3}$ particles were uniformly distributed on the support, and in Fig. 4(c) and (d) there was no observed sintering of $\mathrm{Fe}_{2} \mathrm{O}_{3}$ even after $8 \mathrm{~h}$ time on stream of palmitic acid HTL conversion. 

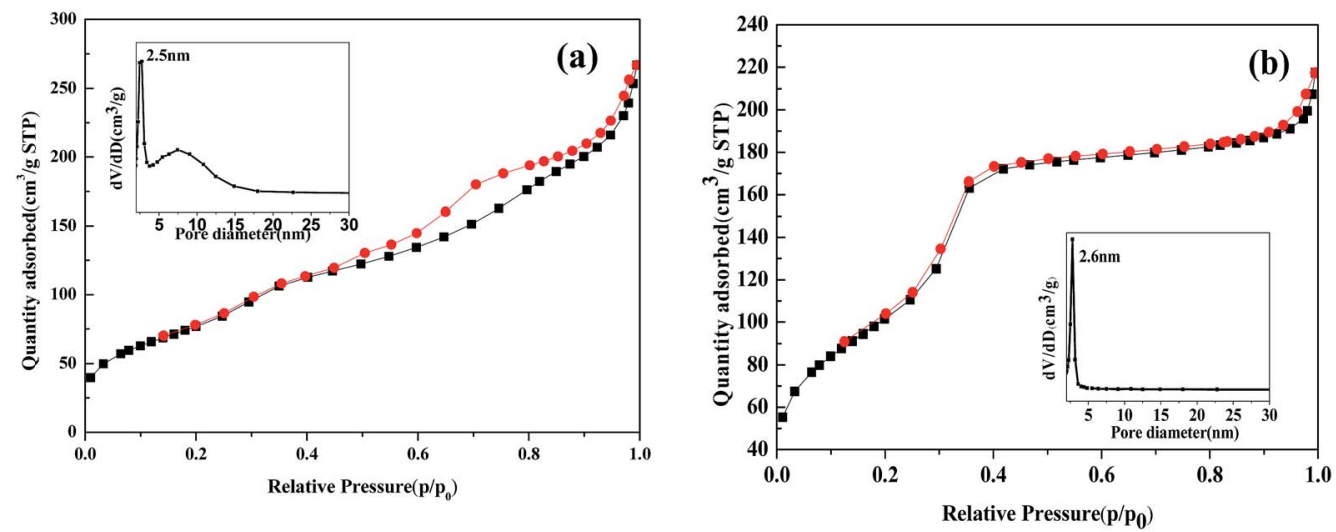

Fig. 3 Isotherms and pore size distributions of catalysts (a) $\mathrm{Fe}_{2} \mathrm{O}_{3} / \mathrm{MCM}-41$ and (b) $\mathrm{Fe}_{2} \mathrm{O}_{3} / \mathrm{Al}-\mathrm{MCM}-41$.
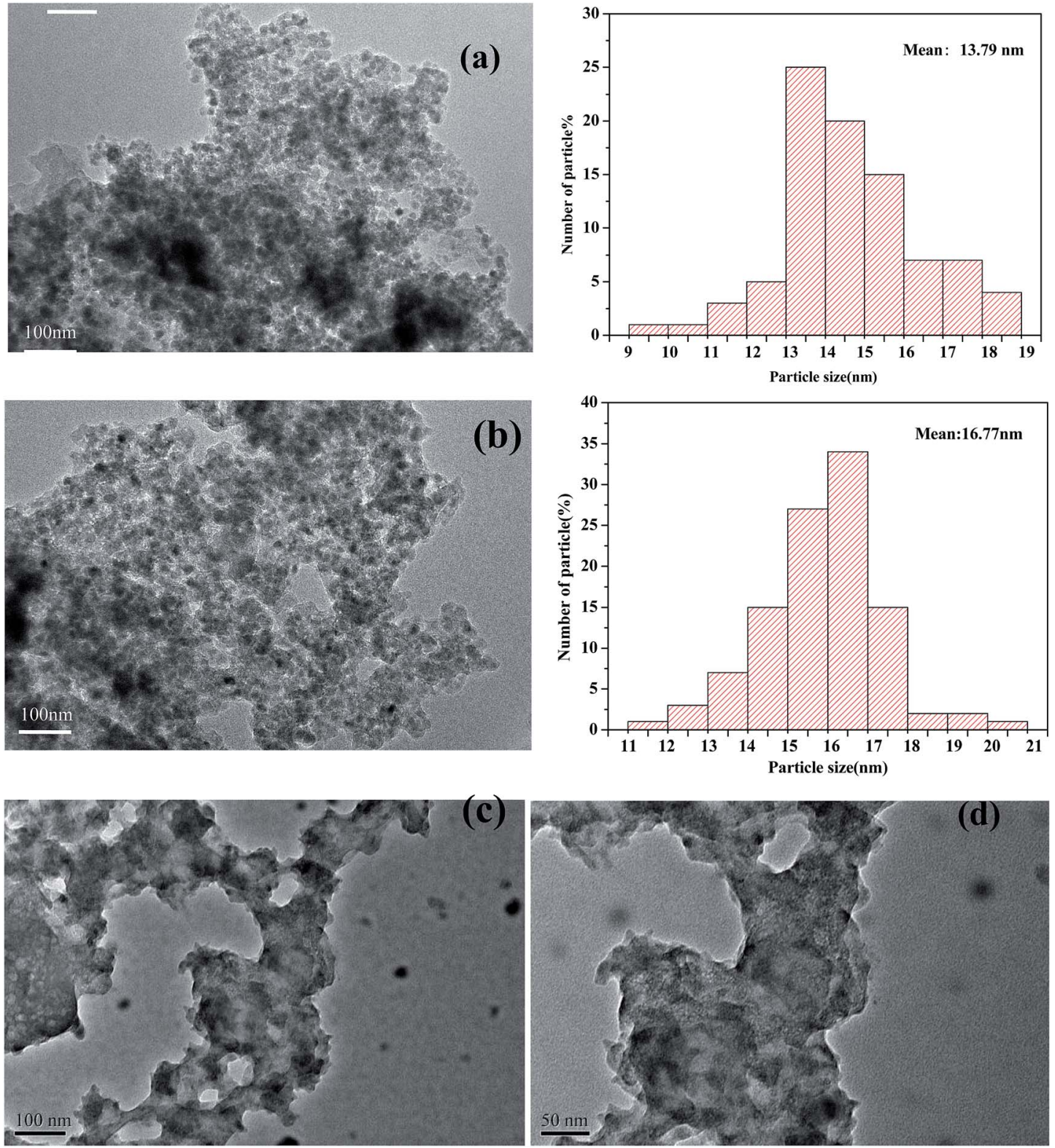

Fig. 4 TEM images of (a) $\mathrm{Fe}_{2} \mathrm{O}_{3} / \mathrm{MCM}-41$, (b) $\mathrm{Fe}_{2} \mathrm{O}_{3} / \mathrm{Al}-\mathrm{MCM}-41$, and (c), (d) $\mathrm{Fe}_{2} \mathrm{O}_{3} / \mathrm{Al}-\mathrm{MCM}-41$ catalysts after $8 \mathrm{~h}$ on stream. 
The ordered mesoporous channels of the support were recognized, and it could be deduced that the magnetic particles were located on the exterior surface of MCM- 41 instead of inside the channels. The $\mathrm{Fe}_{2} \mathrm{O}_{3}$ maghemite cores were confirmed to have been successfully coated by the porous silica "shell" first and further enclosed with Al-MCM-41 to fabricate the supported $\mathrm{Fe}_{2} \mathrm{O}_{3} / \mathrm{Al}-\mathrm{MCM}-41$ catalyst. The consecutive coating method provided an effective approach to obtain the deoxygenation active sites, $\mathrm{Fe}_{2} \mathrm{O}_{3}$, that were well distributed on the decomposition sites, acidic "shell", that made the microalgae HTL and derived biocrude in situ upgrading feasible and practical UV-VisNIR DR spectroscopy has been employed as a promising tool for Fe species analysis. ${ }^{30}$ The reflectance spectra of the $\mathrm{Fe}_{2} \mathrm{O}_{3} / \mathrm{MCM}$ 41 catalysts are shown in Fig. 4. The strong adsorption band at $\sim 300 \mathrm{~nm}$ was assigned to the band-gap transition of the maghemite core. ${ }^{27}$ The $\mathrm{Fe}_{2} \mathrm{O}_{3} / \mathrm{MCM}-41$ catalyst revealed a band centered at $310 \mathrm{~nm}$, while $\mathrm{Fe}_{2} \mathrm{O}_{3} / \mathrm{Al}-\mathrm{MCM}-41$ exhibited bands with maxima at 237 and $313 \mathrm{~nm}$. These were attributed to $\mathrm{Fe}(\mathrm{III})$ complexes with lattice oxygen of the alumina-silicate support, and the appearance of the adsorption bands at wide wavelengths confirmed the strong interaction between iron oxide and the MCM-41 support. A weak band at about $1890 \mathrm{~nm}$ corresponded to the combination vibration band of water molecules. ${ }^{31}$ This band appeared in the spectra of both catalysts.

XPS is versatile surface analysis technique for compositional and chemical state analysis. The binding energies of $\mathrm{Fe} 2 \mathrm{p}_{1 / 2}$ and $\mathrm{Fe} 2 \mathrm{p}_{3 / 2}$ depend on the ionic states of Fe. The positions of the satellite peaks for the $\mathrm{Fe} 2 \mathrm{p}_{1 / 2}$ and $\mathrm{Fe} 2 \mathrm{p}_{3 / 2}$ peaks are also sensitive to the oxidation states, and these peaks have been used to qualitatively determine the ionic states of iron. In the $\mathrm{Fe}$ 2p narrow region of standard spectrum of $\mathrm{Fe}_{2} \mathrm{O}_{3}$, the binding energies of $\mathrm{Fe} 2 \mathrm{p}_{3 / 2}$ and $\mathrm{Fe} 2 \mathrm{p}_{1 / 2}$ are located at 711.8 and $725.3 \mathrm{eV}$, respectively. Fig. 5 shows the XPS spectra of the $\mathrm{Fe}_{2} \mathrm{O}_{3} /$ (Al-)MCM-41 catalysts. There are two obvious energy peaks in the $2 \mathrm{p}$ area of Fe located at 712.0 and $725.5 \mathrm{eV}$ for silica and 712.3 and $725.5 \mathrm{eV}$ for aluminum containing the MCM-41 support. The binding energy of $\mathrm{Fe} 2 \mathrm{p}_{3 / 2}$ for both catalysts was slightly higher than that of the standard spectrum. This could be attributed to the strong interaction of $\mathrm{Fe}_{2} \mathrm{O}_{3}$ nanoclusters with the support. Similar results were also reported by Grosvenor $^{32}$ and Yamashita. ${ }^{33}$ Compared with the previously reported values for silica- and alumina-supported $\mathrm{Fe}_{2} \mathrm{O}_{3}$, it has been confirmed that the main valence state of Fe on the catalysts was +3. Fe $2 \mathrm{p}_{3 / 2}$ of $\mathrm{Fe}_{2} \mathrm{O}_{3}-\mathrm{MCM}-41$ has associated satellite peaks located about $8 \mathrm{eV}$ higher than $\mathrm{Fe} 2 \mathrm{p}_{3 / 2}$. The satellite peak acquired at $719.8 \mathrm{eV}$ was recognized, which is characteristic of $\mathrm{Fe}^{3+}$ in $\mathrm{Fe}_{2} \mathrm{O}_{3}$. Since the XRD patterns of $\gamma-\mathrm{Fe}_{2} \mathrm{O}_{3}$ and $\mathrm{Fe}_{3} \mathrm{O}_{4}$ were remarkably similar, the valence state of the iron oxide particles on the catalysts was further identified as $\mathrm{Fe}_{2} \mathrm{O}_{3}$ from the binding energy peaks in the XPS spectra.

\section{2 $\mathrm{Fe}_{2} \mathrm{O}_{3} /(\mathrm{Al}-) \mathrm{MCM}-41$ for the catalytic decarboxylation of a model compound}

The HTL of chlorella at $300{ }^{\circ} \mathrm{C}$ in subcritical water produced complicated organic compounds. The major components (>1.0 wt\%) were ketones, esters and nitrogen compounds, as illustrated in our group's previous research. ${ }^{23}$ Palmitic acid was chosen as a model compound for catalytic upgrading.

In the absence of hydrogen, the catalyst was employed for the deoxygenation of palmitic acid. As illustrated in Fig. 6, in subcritical water and with the reaction temperature rising from $320{ }^{\circ} \mathrm{C}$ to $350{ }^{\circ} \mathrm{C}$, the palmitic acid conversion was approximately $10.4-24.8 \%$ without catalyst addition. When the $\mathrm{Fe}_{2} \mathrm{O}_{3} /$ MCM-41 magnetic catalyst was employed, the maximum conversion of palmitic acid was $68.1 \%$ at $342{ }^{\circ} \mathrm{C}$, while that of $\mathrm{Fe}_{2} \mathrm{O}_{3} / \mathrm{Al}-\mathrm{MCM}-41$ reached $77.4 \%$ at $350{ }^{\circ} \mathrm{C}$. During fatty acid deoxygenation, the desired product had one less carbon than the corresponding acid. ${ }^{33-35}$ In addition to deoxygenation reactions, a series of reactions could happen spontaneously on the $\mathrm{Fe}_{2} \mathrm{O}_{3} / \mathrm{MCM}-41$ catalyst. These transformations mainly involved isomerization, cracking, hydrogenation, and cyclization reactions. ${ }^{36}$

Consequently, according to the GC chromatogram for the catalytic HTL of palmitic acid with $\mathrm{Fe}_{2} \mathrm{O}_{3} / \mathrm{MCM}-41$ catalyst at $342{ }^{\circ} \mathrm{C}$ in water, $n$-pentadecane was the predominant product obtained from the deoxygenation reactions, while other alkanes $\left(\mathrm{C}_{8}-\mathrm{C}_{14}\right)$ and a certain amount of iso-paraffins were also formed. Judging from the selectivity to pentadecane, the selectivity was $17.3 \%$ at $320{ }^{\circ} \mathrm{C}$ without catalyst; with increasing temperature, the selectivity declined slowly to $2.4 \%$ at $350{ }^{\circ} \mathrm{C}$. After the addition of the supporting magnetic catalyst, the selectivity for pentadecane increased to $32.3-60.7 \%$ with increasing reaction temperature from $320^{\circ} \mathrm{C}$ to $342{ }^{\circ} \mathrm{C}$. When the temperature rose to $350{ }^{\circ} \mathrm{C}$, the selectivity was reduced. This was attributed to
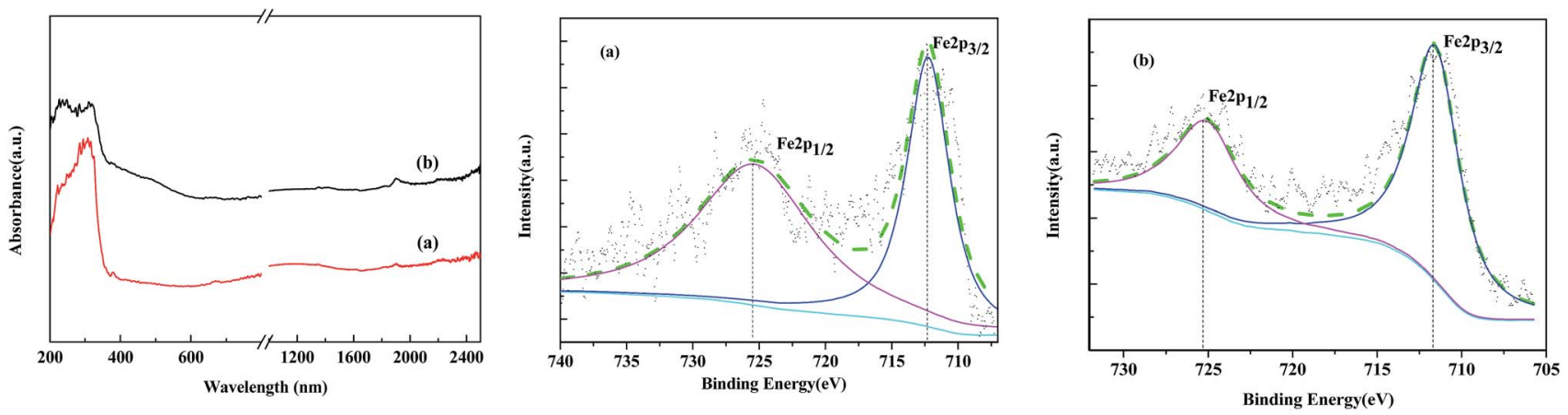

Fig. 5 UV-Vis DR and XPS spectra of the catalysts (a) $\mathrm{Fe}_{2} \mathrm{O}_{3} / \mathrm{MCM}-41$ and (b) $\mathrm{Fe}_{2} \mathrm{O}_{3} / \mathrm{Al}-\mathrm{MCM}-41$. 

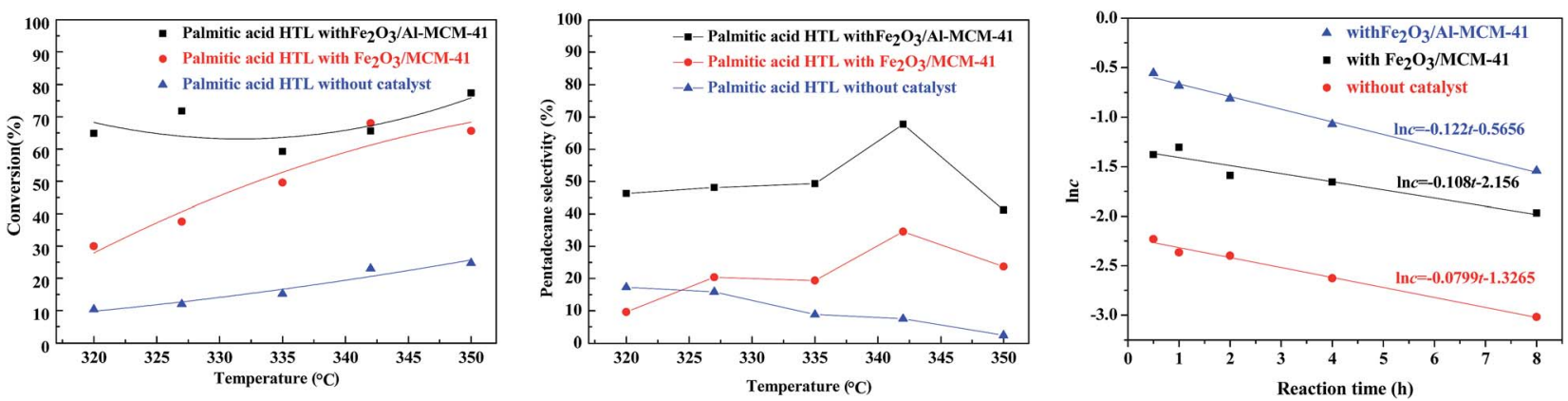

Fig. 6 Effect of temperature on palmitic acid conversion (left) and pentadecane selectivity (middle) without and with catalysts. The correlation of palmitic acid concentration and reaction time at $342{ }^{\circ} \mathrm{C}$ (right). Reaction conditions: $150 \mathrm{mg}$ feed, $10 \mathrm{mg} \mathrm{catalyst,} \mathrm{L/S}=1 / 75 \mathrm{~mL} \mathrm{mg}$.

other prevailing side reactions such as cracking and/or isomerization on the acidic surface of the catalyst.

The existing reports regarding palmitic acid decarboxylation reveal that the overall reaction rate can be considered as first order with respect to palmitic acid. ${ }^{37,38}$ For both catalysts, the reaction rate equation was simulated on the experimental feed conversions at different reaction times. It was confirmed that the consumption rate of palmitic acid fits a first-order equation, and the apparent reaction rate constants were calculated using a batch reactor model. Fig. 6 (right) confirms the linear relationship between the natural logarithm of reactant concentration $(\ln c)$ and reaction time in the tested ranges for noncatalytic and catalytic palmitic acid conversion at $342{ }^{\circ} \mathrm{C}$. The reaction rate constants at different temperatures were calculated, and Table 1 lists the rate constants for the non-catalytic and catalytic decarboxylation at the tested temperatures. The variation in rate constant with temperature followed the Arrhenius equation. The Arrhenius parameters were determined from the unweighted linear regression of $\ln k v s .1 / T$. The activation energy $E_{\mathrm{a}}$ and frequency factor $A$ were calculated and are indicated in Table 2.

The HTL of palmitic acid on both the $\mathrm{Fe}_{2} \mathrm{O}_{3} / \mathrm{MCM}-41$ catalysts was sensitive to temperature. Increasing temperature favored the non-hydrogenation decarboxylation of palmitic acid, and the apparent $E_{\mathrm{a}}$ of catalytic conversion was relatively higher $\left(>300 \mathrm{~kJ} \mathrm{~mol}^{-1}\right)$. The decarboxylation of palmitic acid was initiated by proton attack to produce an alkane with one less carbon. The $\mathrm{p}-\pi$ conjugation of $\mathrm{O}=\mathrm{C}=\mathrm{O}$ led to the formation of large $\pi$ bonding, and a complex was "built" between $\mathrm{COO}^{-}$and $\mathrm{Fe}^{3+}$ in the catalyst, facilitating the decarboxylation of palmitic acid. $\mathrm{Fe}^{3+}$ accelerated intermediate (carboxylate ion) formation and promoted decarboxylation.

\subsection{In situ DRIFT reaction test}

The reaction pathway of palmitic acid decarboxylation on $\mathrm{Fe}_{2} \mathrm{O}_{3} / \mathrm{Al}-\mathrm{MCM}-41$ catalysts was illustrated in our previous study, ${ }^{23}$ and $\mathrm{CO}_{2}$ desorption from the surface of the catalyst was identified as the rate-limiting step. Fatty acids and amino acids were abundant products of microalgae HTL or hydrolysis, and the interaction of palmitic acid and glutamic acid in the HTL process would be elucidated further. In situ DRIFTS was employed to investigate the formation and reactivity of surface species on the magnetic $\mathrm{Fe}_{2} \mathrm{O}_{3} / \mathrm{Al}-\mathrm{MCM}-41$ catalyst during the decarboxylation of palmitic acid with added glutamic acid. Scans were taken every $5{ }^{\circ} \mathrm{C}$ starting at $115{ }^{\circ} \mathrm{C}$.

As illustrated in Fig. 8, when the temperature increased to $195{ }^{\circ} \mathrm{C}$, a band at $2349 \mathrm{~cm}^{-1}$ emerged, which was assigned to the asymmetric stretching vibration peak of $\mathrm{O}=\mathrm{C}=\mathrm{O}$. The band at $1450 \mathrm{~cm}^{-1}$ weakened, which was assigned to the stretching vibration of carboxylate anion $\left(-\mathrm{COO}^{-}\right)$in $\mathrm{L}$-glutamic

Table 2 Kinetic parameters of palmitic acid HTL conversion

\begin{tabular}{lll}
\hline & $\begin{array}{l}\text { Frequency factor } \\
A\left(\mathrm{~h}^{-1}\right)\end{array}$ & $\begin{array}{l}\text { Activation energy } \\
E_{\mathrm{a}}\left(\mathrm{kJ} \mathrm{mol}^{-1}\right)\end{array}$ \\
\hline Non-catalytic & $3.50 \times 10^{22}$ & 320.64 \\
With $\mathrm{Fe}_{2} \mathrm{O}_{3} / \mathrm{MCM}-41$ & $3.16 \times 10^{23}$ & 330.66 \\
With $\mathrm{Fe}_{2} \mathrm{O}_{3} / \mathrm{Al}-\mathrm{MCM}-41$ & $1.16 \times 10^{24}$ & 336.76
\end{tabular}

Table 1 Reaction rate constants for the HTL conversion of palmitic acid at different temperatures

\begin{tabular}{llll}
\hline & $k / \mathrm{mol}^{-1} \mathrm{~L} \mathrm{~h}^{-1}$ & & \\
\cline { 2 - 4 } Temperature/K & Without catalyst & With $\mathrm{Fe}_{2} \mathrm{O}_{3} / \mathrm{MCM}-41$ & With Fe $\mathrm{O}_{3} / \mathrm{Al}^{-M C M-41}$ \\
\hline 593.15 & 0.00775 & 0.00794 & 0.00811 \\
600.15 & 0.0143 & 0.0182 & 0.0208 \\
608.15 & 0.0375 & 0.0427 & 0.0566 \\
615.15 & 0.0799 & 0.108 & 0.122 \\
623.15 & 0.164 & 0.185 & 0.204
\end{tabular}


acid. ${ }^{39} \mathrm{~A}$ band at $667 \mathrm{~cm}^{-1}$ re-appeared and corresponded to the bending peak of $\mathrm{O}=\mathrm{C}=\mathrm{O}$. The desorption of weakly adsorbed $\mathrm{CO}_{2}$ on $\mathrm{Fe}_{2} \mathrm{O}_{3} / \mathrm{Al}-\mathrm{MCM}-41$ occurred at about $175{ }^{\circ} \mathrm{C}$. The decarboxylation of glutamic acid occurred at $195{ }^{\circ} \mathrm{C}$ and led the re-appearance of the $\mathrm{O}=\mathrm{C}=\mathrm{O}$ peak. This means that glutamic acid decarboxylation was initiated at $195{ }^{\circ} \mathrm{C} .{ }^{40}$ The shoulder peak at $1760 \mathrm{~cm}^{-1}$ could be due to the vibration of $\mathrm{C}=\mathrm{O}$ in carboxylic acid; this peak emerged at $215^{\circ} \mathrm{C}$ and increased with increasing temperature. This indicated that glutamic acid decarboxylation occurred first, and palmitic acid then dissociated to form carboxylate ion, which was decarboxylated by proton attack to produce the alkane with one less carbon. The intramolecular dehydration of glutamic acid produced carboxyl pyrrolidinone, and the ionization of the carboxyl group occurred. This is why decarboxylation on the $\mathrm{Fe}_{2} \mathrm{O}_{3} / \mathrm{Al}-\mathrm{MCM}-41$ catalyst occurred at temperatures lower than $200{ }^{\circ} \mathrm{C}$. The vibration peak at $1290 \mathrm{~cm}^{-1}$ was assigned to the stretching of $\mathrm{C}-\mathrm{N}^{41,42}$ and became notable at $255^{\circ} \mathrm{C}$. It was evident that amide formed at this temperature.

As demonstrated in Fig. 7, the band at $2349 \mathrm{~cm}^{-1}$ disappeared at $255{ }^{\circ} \mathrm{C}$, and it was deduced that glutamic acid decomposed to produce $\mathrm{CO}_{2}$, and $\mathrm{CO}_{2}$ desorption was the ratelimiting step of decarboxylation. ${ }^{43}$ Taking the activation energy of palmitic acid conversion into consideration, it was confirmed that the decarboxylation or deamination of amino acids occurred at lower temperatures than the decarboxylation or decarbonylation of fatty acids in the HTL oil. Tuning the adsorption strength of $\mathrm{CO}_{2}$ on the catalyst may improve the formation of carboxyl anion and enhance the selectivity of palmitic acid decarboxylation to alkanes.

\subsection{GC-MS analysis}

Palmitic acid and glutamic acid were subjected to co-HTL at $320{ }^{\circ} \mathrm{C}$, and the derived $\mathrm{CH}_{2} \mathrm{Cl}_{2}$-soluble products were gathered for GC-MS analysis to identify the reaction pathways. As illustrated in Table 3, the main products of the binary mixture were hexadecanamide (32.00\%), 4-hydroxyl-butanoic acid $(24.31 \%)$, pyrrolidone (16.10\%), and tetradecanoic acid (9.08\%) by weight. According to their chemical origins, the products could be
Table 3 Major products from the HTL reaction of palmitic acid and Lglutamic acid on $\mathrm{Fe}_{2} \mathrm{O}_{3} / \mathrm{Al}-\mathrm{MCM}-41$

\begin{tabular}{llr}
\hline Name of product & Chemical formula & wt\% \\
\hline Pentadecane & $\mathrm{C}_{15} \mathrm{H}_{32}$ & 4.46 \\
4-Hydroxy-butanoic acid & $\mathrm{C}_{4} \mathrm{H}_{8} \mathrm{O}_{3}$ & 24.31 \\
1-Propyl-2-pyrrolidinone & $\mathrm{C}_{7} \mathrm{H}_{13} \mathrm{NO}$ & 7.03 \\
2-Tetradecanone & $\mathrm{C}_{14} \mathrm{H}_{28} \mathrm{O}$ & 1.98 \\
2-Pyrrolidinone & $\mathrm{C}_{4} \mathrm{H}_{7} \mathrm{NO}$ & 9.08 \\
n-Decanoic acid & $\mathrm{C}_{10} \mathrm{H}_{20} \mathrm{O}_{2}$ & 1.92 \\
Tetradecanoic acid & $\mathrm{C}_{14} \mathrm{H}_{28} \mathrm{O}_{2}$ & 9.08 \\
Pentadecanoic acid & $\mathrm{C}_{15} \mathrm{H}_{30} \mathrm{O}_{2}$ & 2.79 \\
Valeric acid, undec-2-enyl ester & $\mathrm{C}_{4} \mathrm{H}_{7} \mathrm{O}_{4}$ & 4.53 \\
Hexadecanamide & $\mathrm{C}_{16} \mathrm{H}_{33} \mathrm{NO}$ & 32.00 \\
& & \\
\hline
\end{tabular}

\section{Overall reaction}

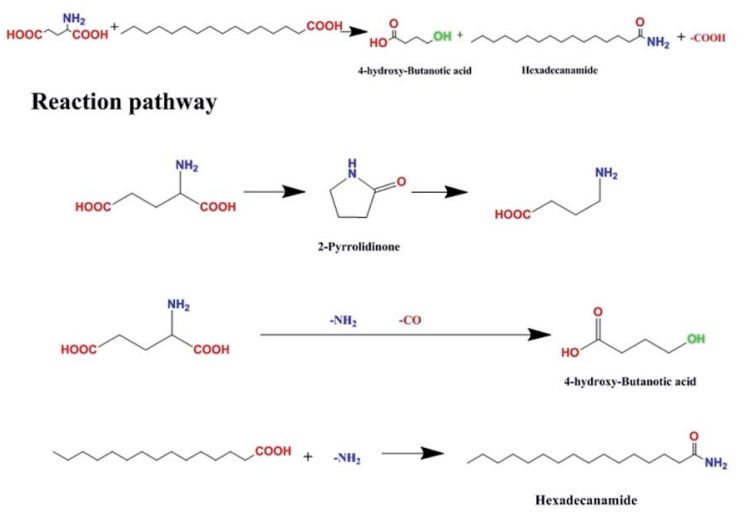

Fig. 8 Proposed reaction pathway for the HTL of palmitic acid and glutamic acid on $\mathrm{Fe}_{2} \mathrm{O}_{3} / \mathrm{Al}-\mathrm{MCM}-41$ catalyst.

classified into three groups derived from glutamic acid, from palmitic acid, and from the binary interaction of amino acid and fatty acid.

The possible reaction pathways were deduced and are illustrated in Fig. 8. Amides with the general formula $\mathrm{R}-\mathrm{N}\left(\mathrm{C}_{x} \mathrm{H}_{y}\right)^{n}$ were the major products and were generated by the replacement of the hydroxyl group of palmitic acid with an amino group
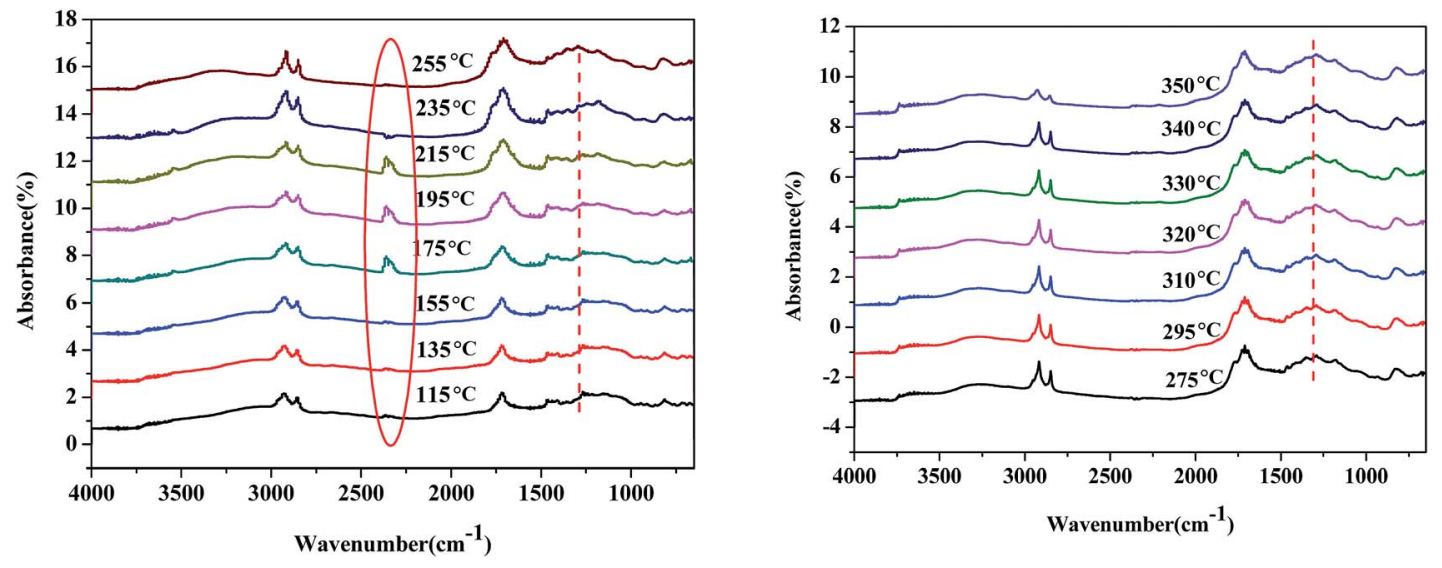

Fig. 7 In situ DRIFT spectra of palmitic acid and glutamic acid during conversion on $\mathrm{Fe}_{2} \mathrm{O}_{3} / \mathrm{Al}-\mathrm{MCM}-41$ catalyst. 
(route 4). Meanwhile, a certain amount of alkanes were produced via palmitic acid decomposition. Hydroxyl butanoic acid and pyrrolidone were derived from glutamic acid deamination and decarbonylation (route 3) and from intermolecular dehydration and decarboxylation (route 2). The latter, decarboxylation, is favored for biocrude upgrading.

For green fuel applications, the binary interaction of amino acid and fatty acid should be suppressed. We acknowledge that amide was formed at slightly higher temperature than the decarboxylation of palmitic acid, as was illustrated in the DRIFT test. Further efforts will focus on fabricating well-designed catalysts to facilitate deoxygenation and deamination.

\section{Conclusions}

$\mathrm{Fe}_{2} \mathrm{O}_{3} / \mathrm{MCM}-41$ magnetic catalysts were designed and fabricated in a modified assembling method. An $\mathrm{Fe}_{2} \mathrm{O}_{3}$ "core" was prepared by precipitation, coated by porous silica, and supported on Al-MCM-41 synthesized using clinoptilolite as an aluminum source. XRD, TEM, XPS, and UV-Vis-NIR characterizations confirmed that $20-30 \mathrm{~nm} \gamma-\mathrm{Fe}_{2} \mathrm{O}_{3}$ particles were well dispersed on the mesoporous support.

The magnetic $\mathrm{Fe}_{2} \mathrm{O}_{3}$ /MCM-41 catalysts showed good performance for chlorella HTL and upgrading of the derived biocrude. In the temperature range of $320-350{ }^{\circ} \mathrm{C}$ and under subcritical water, palmitic acid conversion was improved by $43-54 \%$ with $\mathrm{Fe}_{2} \mathrm{O}_{3} / \mathrm{Al}-\mathrm{MCM}-41$ catalyst in the absence of $\mathrm{H}_{2}$. The activation energy for the catalytic decarboxylation of palmitic acid was $336.76 \mathrm{~kJ} \mathrm{~mol}^{-1}$ on $\mathrm{Fe}_{2} \mathrm{O}_{3} / \mathrm{Al}-\mathrm{MCM}-41$.

In situ DRIFTS reaction test demonstrated that the decarboxylation initiation temperature was $195^{\circ} \mathrm{C}$, and the produced $\mathrm{CO}_{2}$ desorbed at $255^{\circ} \mathrm{C}$. A good alternative may be to "distillate" the produced $\mathrm{CO}_{2}$ from the reaction system via process intensification.

The HTL reaction pathways of the binary mixture of glutamic acid and palmitic acid were elucidated by product analysis, and the chemical origins of the main products were proposed.

\section{Conflicts of interest}

There are no conflicts to declare.

\section{Acknowledgements}

This work was supported by the National Natural Science Foundation of China (No. 21376230) and The National Key Technology R\&D Program of China (No. 2011BAD14B00).

\section{References}

1 A. L. Ahmad, N. H. M. Yasin, C. J. C. Derek and J. K. Lim, Renewable Sustainable Energy Rev., 2011, 15, 584-593.

2 N. Yan and X. Chen, Nature, 2015, 524, 155-157.

3 O. Ellabban, H. Abu-Rub and F. Blaabjerg, Renewable Sustainable Energy Rev., 2014, 39, 748-764.

4 D.-T. Tran, J.-S. Chang and D.-J. Lee, Appl. Energy, 2017, 185, 376-409.
5 P. Biller, A. B. Ross, S. C. Skill, A. Lea-Langton, B. Balasundaram, C. Hall, R. Riley and C. A. Llewellyn, Algal Res., 2012, 1, 70-76.

6 S. Zou, Y. Wu, M. Yang, C. Li and J. Tong, Energy Fuels, 2009, 23, 3753-3758.

7 B. Chakinala and W. Swaaij, Ind. Eng. Chem. Res., 2009, 49, 1113-1122.

8 P. Duan, Energy Environ. Sci., 2011, 4, 1447-1456.

9 M. Y. Bian and C. Promdej, Ind. Eng. Chem. Res., 2011, 50, 8492-8497.

10 P. Duan, Ind. Eng. Chem. Res., 2010, 50, 52-61.

11 U. Jena, K. C. Das and J. R. Kastner, Appl. Energy, 2012, 98, 368-375.

12 M. Shahinuzzaman, Z. Yaakob and Y. Ahmed, Renewable Sustainable Energy Rev., 2017, 77, 1375-1384.

13 N. S. Shamsul, S. K. Kamarudin and N. A. Rahman, Renewable Sustainable Energy Rev., 2017, 80, 538-549.

14 Y. Chen, Y. Wu, R. Ding, P. Zhang, J. Liu, M. Yang and P. Zhang, AIChE J., 2015, 61, 1118-1128.

15 Q. Lin, Y. Chen, Y. Tang, K. Wu, M. Yang, H. Hu and Y. Wu, Microporous Mesoporous Mater., 2017, 250, 120-127.

16 T. Yeh, S. Linic and P. E. Savage, ACS Sustainable Chem. Eng., 2014, 2, 2399-2406.

17 J. Fu, C. Yang, J. Wu, J. Zhuang, Z. Hou and X. Lu, Fuel, 2015, 139, 678-683.

18 D. Kim, D. R. Vardon, D. Murali, B. K. Sharma and T. J. Strathmann, ACS Sustainable Chem. Eng., 2016, 4, 1775-1784.

19 S. Idesh, S. Kudo, K. Norinaga and J.-i. Hayashi, Energy Fuels, 2013, 27, 4796-4803.

20 W. Li, Y. Gao, S. Yao, D. Ma and N. Yan, Green Chem., 2015, 17, 4198-4205.

21 J. Wu, J. Shi, J. Fu, J. A. Leidl, Z. Hou and X. Lu, Sci. Rep., 2016, 6, 27820.

22 Y. Wang, S. De and N. Yan, Chem. Commun., 2016, 52, 62106224.

23 J. Bian, Q. Zhang, P. Zhang, L. Feng and C. Li, Catal. Today, 2017, 293, 159-166.

24 S. Karnjanakom, T. Suriya-umporn, A. Bayu, S. Kongparakul, C. Samart, C. Fushimi, A. Abudula and G. Guan, Energy Convers. Manage., 2017, 142, 272-285.

25 E. Santillan-Jimenez, R. Pace, S. Marques, T. Morgan, C. McKelphin, J. Mobley and M. Crocker, Fuel, 2016, 180, 668-678.

26 N. Asikin-Mijan, H. V. Lee, Y. H. Taufiq-Yap, G. AbdulkremAlsultan, M. S. Mastuli and H. C. Ong, Energy Convers. Manage., 2017, 141, 325-338.

27 Y. Ling, M. Long, P. Hu, Y. Chen and J. Huang, J. Hazard. Mater., 2014, 264, 195-202.

28 L. Čapek, V. Kreibich, J. Dědeček, T. Grygar, B. Wichterlová, Z. Sobalík, J. A. Martens, R. Brosius and V. Tokarová, Microporous Mesoporous Mater., 2005, 80, 279-289.

29 J. Bian, Q. Zhang, X. Min, S. Zhang, L. Feng and C. Li, Process Saf. Environ. Prot., 2016, 101, 117-123.

30 J. Gurgul, K. Łątka, I. Hnat, J. Rynkowski and S. Dzwigaj, Microporous Mesoporous Mater., 2013, 168, 1-6. 
31 G. Spoto, A. Zecchina, G. Berlier, S. Bordiga, M. G. Clerici and L. Basini, J. Mol. Catal. A: Chem., 2000, 158, 107-114.

32 A. P. Grosvenor, B. A. Kobe, M. C. Biesinger and N. S. McIntyre, Surf. Interface Anal., 2004, 36, 1564-1574.

33 T. Yamashita and P. Hayes, Appl. Surf. Sci., 2008, 254, 24412449.

34 P. T. Huyen, L. T. H. Nam, T. Q. Vinh, C. Martínez and V. I. Parvulescu, Catal. Today, 2017, DOI: 10.1016/ j.cattod.2017.03.040.

35 C. Miao, O. Marin-Flores, S. D. Davidson, T. Li, T. Dong, D. Gao, Y. Wang, M. Garcia-Pérez and S. Chen, Fuel, 2016, 166, 302-308.

36 H. Xin, K. Guo, D. Li, H. Yang and C. Hu, Appl. Catal., B, 2016, 187, 375-385.

37 S. V. Vassilev and C. G. Vassileva, Fuel, 2016, 181, 1-33.
38 C. Yang, R. Nie, J. Fu, Z. Hou and X. Lu, Bioresour. Technol., 2013, 146, 569-573.

39 L. Guo, M. Meng and Y. Zha, Chin. J. Catal., 2006, 27, 189194.

40 L. Hermida, A. Z. Abdullah and A. R. Mohamed, Renewable Sustainable Energy Rev., 2015, 42, 1223-1233.

41 B. de Campos Vidal and M. L. S. Mello, Micron, 2011, 42, 283-289.

42 O. Francioso, D. Montecchio, P. Gioacchini, L. Cavani, C. Ciavatta, O. Trubetskoj and O. Trubetskaya, Geoderma, 2009, 152, 264-268.

43 A. A. Kamnev, A. G. Shchelochkov, Y. D. Perfiliev, P. A. Tarantilis and M. G. Polissiou, J. Mol. Struct., 2001, 563, 565-572. 